\title{
Turnover rate of anti-D IgG injected during pregnancy
}

\author{
J EKLUND, M HERMANN, H KJELLMAN, PAULA POHJA
}

\begin{abstract}
Anti-D IgG was injected into $15 \mathrm{Rh}$-negative women in the 28th week of gestation and into three non-pregnant women. The uptake of anti-D after the intramuscular injections was calculated by measuring the concentration of antibody in the plasma with an autoanalyser. The biological half life and the catabolic rate of anti-D IgG were calculated according to a compartmental model. The recovery in vivo of anti-D IgG was on average $24 \%$ in the non-pregnant women and $21 \%$ in the pregnant women. The half lives of anti-D IgG were 24 and 21 days, respectively. With a dose of $125 \mu \mathrm{g}$ the plasma anti-D concentration was less than $1 \mathrm{ng} / \mathrm{ml}$ at about 10 weeks after the injection. With double the dose the concentration at delivery was at least $1 \mathrm{ng} / \mathrm{ml}$.

Although $250 \mu \mathrm{g}$ of anti-D IgG seems to be effective when given in the 28th week of gestation, the great individual variations in uptake and recovery rates will lead to occasional cases of Rh-immunisation during pregnancy despite all routine regimens.
\end{abstract}

\section{Introduction}

There is good evidence that giving anti-D immunoglobulin both antenatally and at delivery has substantially reduced the incidence of $\mathrm{Rh}$-immunisation. ${ }^{1-3}$ Moreover, when antenatal treatment with anti-D IgG is indicated a single dose of $250 \mu \mathrm{g}$ in the 28 th week of gestation is effective. A smaller dose and a different timing may be just as adequate and more economical but have not been tried.

Since there is almost no information available on the biological half life of anti-D IgG, which determines the effectiveness of different dose-schedules, we studied this question in pregnant and non-pregnant women.

\section{Subjects and methods}

Fifteen Rh-negative pregnant women were given anti-D IgG intramuscularly at 28 weeks' gestation. The doses were $125 \mu \mathrm{g}$ in eight and $250 \mu \mathrm{g}$ in seven of the women. Three non-pregnant $\mathrm{Rh}$ negative women were given the smaller dose. The anti-D IgG preparation (Rhesonativ) used was fractionated by a modified cold ethanol method by Kabi Ab, Stockholm, Sweden. The anti-D content of this preparation was determined by the direct method of HughesJones and Stevenson. ${ }^{4}$ The aim and scope of the study were carefully explained to the women.

Blood samples from the pregnant women were drawn before and $1,2,3,5,7,9$, and 11 weeks after the injection and at delivery. In the three non-pregnant women the first postinjection sample was taken three days after the injection followed by samples at the same intervals

Finnish Red Cross Blood Transfusion Service, SF-00310 Helsinki 31, Finland

J EKLUND, MD, medical adviser

PAULA POHJA, MSC, assistant biochemist

Department of Obstetrics, Centrallasarettet, S-351 85 Växjö, Sweden M HERMANN, MD, chief obstetrician

Kabi Blood Products Division, Kabi Ab, S-112 87 Stockholm, Sweden H KJELLMAN, MPHARM, BM, scientific manager (present address: Armour Pharma, Krefeld, West-Germany) as above and an additional sample 12 weeks after the injection. The plasma samples were frozen immediately at $-20^{\circ} \mathrm{C}$ and analysed in series.

$\mathrm{ABO}$ and $\mathrm{Rh}$ grouping was done on all the women and their newborn infants. The women who delivered Rh-positive infants were given 250 $\mu \mathrm{g}$ of anti-D IgG within 24 hours of delivery.

Anti-D was measured in the plasma samples by the AutoAnalyzer method. ${ }^{5}$ The lowest plasma concentration of anti-D which could be reliably detected with this method was $1 \mathrm{ng} / \mathrm{ml}$. The plasma volume was estimated to be $45 \mathrm{ml} / \mathrm{kg}$ body weight for non-pregnant women and $50 \mathrm{ml} / \mathrm{kg}$ for pregnant women. ${ }^{6}$ The biological half life was calculated by the method of residuals, the usual technique for resolving a curve into its various exponential components. ${ }^{7}$ The recovery in vivo of the injected anti-D IgG was calculated using the formula

$100 \times$ plasma volume $(\mathrm{ml} / \mathrm{kg}) \times$ body weight $\times$ peak value of anti- $\mathrm{D}$. injected dose of anti-D IgG

\section{Results}

The biological half life of anti-D IgG after an intramuscular injection of $125 \mu \mathrm{g}$ in the three non-pregnant women was 23.9 days. The maximum concentration was reached after seven days. Anti-D was no longer detectable a mean of $92 \cdot 7 \pm$ (1 SD) 4.8 days after the injection (table I).

Of the eight pregnant women given $125 \mu \mathrm{g}$ of anti-D IgG, three were delivered of $\mathrm{Rh}$-negative infants. The biological half lives of anti-D IgG in two of these women were 16.2 and 21.3 days. In the third we could not calculate the half life owing to the very low uptake of the injected anti-D IgG. The maximum concentrations of anti-D in the first two women were $8.0 \mathrm{ng} / \mathrm{ml}$ and $9.0 \mathrm{ng} / \mathrm{ml}$. In the third it was only $2.9 \mathrm{ng} / \mathrm{ml}$. The concentration of anti-D reached the plasma level of $1 \mathrm{ng} / \mathrm{ml}$ a mean of $66+4 \cdot 7$ days after the injection.

The mean half life of anti-D IgG in four of the five women who received $125 \mu \mathrm{g}$ anti-D IgG and who delivered Rh-positive infants was 21.7 days. The maximum concentrations were $5 \cdot 7,5 \cdot 8,8.8$, and $11.6 \mathrm{ng} / \mathrm{ml}$, and the anti-D was no longer detectable $71.4 \pm 10.0$ days after the injection. In the fifth woman the highest level was only $2 \cdot 2$ $\mathrm{ng} / \mathrm{ml}$. The concentration of anti-D was less than $1 \mathrm{ng} / \mathrm{ml}$ after 21 days, which did not permit an accurate calculation of the half life (table I).

Three of the seven women who received $250 \mu \mathrm{g}$ of anti-D IgG were delivered of an Rh-negative infant. Their mean half life of anti-D was 23.4 days. The maximum concentration was $15.0 \mathrm{ng} / \mathrm{ml}$. The corresponding figures for the four women delivered of an Rh-positive infant were 19.5 days and $17.1 \mathrm{ng} / \mathrm{ml}$ (table II).

The mean value $(+1$ SD) for the time of the lowest detectable concentration of anti-D was $118.0 \pm 6.8$ days in the women with Rhnegative infants and $119.7 \pm 14.8$ days in those with Rh-positive infants.

When the two women with very low maximum concentrations were excluded, the mean recovery in vivo of anti-D IgG was $24 \%(23-27)$ in the non-pregnant women and $21 \%(14-32)$ in the pregnant women (table III)

\section{Discussion}

The average biological half life of normal IgG has been estimated from turnover studies with ${ }^{125}$ I-labelled human gammaglobulin to be 23 days. ${ }^{8} 9$ Our study shows clearly that the half life of anti-D IgG measured by specific antibody activity is no different from that of normal IgG-that is, 24 days in nonpregnant women and 21 days in pregnant $\mathrm{Rh}$-negative women. As might be expected, the figure for the non-pregnant women was closely comparable with the value obtained in $\mathrm{Rh}$-negative male volunteers. ${ }^{10}$ The lower mean value in the pregnant women reflects the well-documented transfer of $10-15 \%$ of the antibody across the placenta into the fetal circulation. 
Smith et al found that the concentration of anti-D IgG reached its maximum two to four days after the intramuscular injection, corresponding to an average of $40 \%$ of the injected dose. ${ }^{10}$ Jouvenceaux reported almost the same recovery in vivo, but five to 10 days after the injection. ${ }^{11}$ In our study the recovery rates were estimated to be $23-27 \%$ in the non-pregnant women and $14-32 \%$ in the pregnant women (excluding two patients who had a very low uptake of the injected doses).

In the woman with low anti-D concentrations who delivered an Rh-positive infant there may have been increased consumption of the injected antibody due to transplacental haemorrhages from the Rh-positive fetus. Local loss of intramuscularly injected gammaglobulin has been recorded in earlier studies, but the precise mechanism is not well documented. ${ }^{12}{ }^{13}$ Furthermore, it has been suggested that, for example, muscular activity may influence the extent of the resorption of the injected dose. ${ }^{9} 14$ negative women. Our results show that with a single dose of $125 \mu \mathrm{g}$ at the 28th week of gestation the plasma concentration was less than $1 \mathrm{ng} / \mathrm{ml}$ about 10 weeks after the injection. This dose is therefore insufficient if the suppression of Rh-immunisation during pregnancy depends on the presence of measurable amounts of anti-D IgG in the plasma at delivery.

A schedule based on a single dose of $250 \mu \mathrm{g}$ of anti-D IgG in the 28 th week, however, gave a plasma concentration of anti-D of at least $1 \mathrm{ng} / \mathrm{ml}$ at delivery, which is probably enough for the purpose. There were no significant differences in the mean time of the lowest detectable plasma concentrations of anti-D between women who delivered $\mathrm{Rh}$-negative infants and those who delivered $\mathrm{Rh}$-positive infants. The striking individual variations in both uptake and recovery rates combined with the eventual consumption of the injected antibody during pregnancy will be responsible for occasional cases of $\mathrm{Rh}$-immunisation during pregnancy despite routine use of anti-D IgG antenatally.

TABLE I-Biological half life and maximum and minimum detectable plasma concentrations of anti-D IgG after intramuscular injection of $125 \mu \mathrm{g}$ of anti-D immunoglobulin in three non-pregnant and eight pregnant women at 28 weeks' gestation

\begin{tabular}{|c|c|c|c|c|c|}
\hline $\begin{array}{c}\text { Rh-negative } \\
\text { women }\end{array}$ & $\begin{array}{c}\text { No of } \\
\text { women }\end{array}$ & $\begin{array}{c}\text { Weight } \\
\text { (kg) }\end{array}$ & $\begin{array}{l}\text { Biological } \\
\text { half life } \\
\text { (days) }\end{array}$ & $\begin{array}{c}\text { Maximum } \\
\text { concentration } \\
(\mathrm{ng} / \mathrm{ml})^{*}\end{array}$ & $\begin{array}{c}\text { Mean No }( \pm 1 \mathrm{SD}) \\
\text { of days after } \\
\text { injection when } \\
\text { value fell below } \\
<1.0 \mathrm{ng} / \mathrm{ml} \\
\end{array}$ \\
\hline $\begin{array}{l}\text { Non-pregnant } \\
\text { Pregnant, Rh-negative infants } \\
\text { Pregnant, Rh-positive infants }\end{array}$ & $\begin{array}{l}3 \\
3 \\
5\end{array}$ & $\begin{array}{l}62(52-67) \\
62(49-70) \\
65(59-74)\end{array}$ & $\begin{array}{l}23 \cdot 9(18 \cdot 0-29 \cdot 2) \\
18 \cdot 8(16 \cdot 2-21 \cdot 3) \\
21 \cdot 7(17 \cdot 9-23 \cdot 7)\end{array}$ & $\begin{array}{r}11 \cdot 0(9 \cdot 6-12 \cdot 4) \\
8 \cdot 5(8 \cdot 0-9 \cdot 0) \\
8 \cdot 0(5 \cdot 8-11 \cdot 6)\end{array}$ & $\begin{array}{l}92 \cdot 7 \pm 4 \cdot 8 \\
66 \cdot 7 \pm 4 \cdot 7 \\
71 \cdot 4 \pm 10 \cdot 0\end{array}$ \\
\hline
\end{tabular}

* Maximum anti-D concentrations in one woman who delivered an $\mathrm{Rh}$-negative infant $(2.8 \mathrm{ng} / \mathrm{ml})$ and one who delivered an $\mathrm{Rh}$-positive infant $(2 \cdot 2 \mathrm{ng} / \mathrm{ml})$ are not included.

TABLE II-Biological half life and maximum and minimum detectable plasma concentration of anti-D IgG after intramuscular injection of $250 \mu \mathrm{g}$ of anti-D immunoglobulin in seven pregnant women at 28 weeks' gestation

\begin{tabular}{lccccc}
\hline $\begin{array}{l}\text { Rh-negative women } \\
\text { giving birth to }\end{array}$ & $\begin{array}{c}\text { No of } \\
\text { women }\end{array}$ & $\begin{array}{c}\text { Weight } \\
(\mathrm{kg})\end{array}$ & $\begin{array}{c}\text { Biological } \\
\text { half life } \\
\text { (days) }\end{array}$ & $\begin{array}{c}\text { Maximum anti-D } \\
\text { concentration } \\
(\mathrm{ng} / \mathrm{ml})\end{array}$ & $\begin{array}{c}\text { Mean No(士1 SD) } \\
\text { of days after } \\
\text { injection when } \\
\text { value fell } \\
<1 \cdot 0 \mathrm{ng} / \mathrm{ml}\end{array}$ \\
\hline $\begin{array}{l}\text { Rh-negative infants } \\
\text { Rh-positive infants }\end{array}$ & 3 & $66(64-66)$ & $\begin{array}{c}23 \cdot 4(17 \cdot 8-29 \cdot 6) \\
19 \cdot 5(16 \cdot 6-24 \cdot 2)\end{array}$ & $\begin{array}{c}15 \cdot 0(13 \cdot 3-17 \cdot 5) \\
17 \cdot 1(10 \cdot 8-23 \cdot 0)\end{array}$ & $\begin{array}{l}118 \cdot 0 \pm 6 \cdot 8 \\
119 \cdot 7 \pm 14 \cdot 8\end{array}$ \\
\hline
\end{tabular}

TABLE III-Recovery in vivo of anti-D IgG in 17 women expressed as percentage of injected dose

\begin{tabular}{|c|c|c|}
\hline $\begin{array}{l}\text { Rh-negative } \\
\text { women }\end{array}$ & $\begin{array}{l}\text { No of } \\
\text { women }\end{array}$ & $\begin{array}{l}\text { Mean recovery } \\
\text { in vivo } \\
\text { (range) ("o) }\end{array}$ \\
\hline $\begin{array}{l}125 \mu \mathrm{g} \text { anti-D: } \\
\text { Non-pregnant } \\
\text { Pregnant, Rh-negative infants* } \\
\text { Pregnant, Rh-positive infants }\end{array}$ & $\begin{array}{l}3 \\
3 \\
5\end{array}$ & $\begin{array}{l}24(23-27) \\
20(16-25) \\
20(16-26)\end{array}$ \\
\hline $\begin{array}{l}250 \mu \mathrm{g} \text { anti-D: } \\
\text { Pregnant, } \mathrm{Rh} \text {-negative infants } \\
\text { Pregnant, } \mathrm{Rh} \text {-positive infants }\end{array}$ & $\begin{array}{l}3 \\
4\end{array}$ & $\begin{array}{l}20(17-23) \\
24(14-32)\end{array}$ \\
\hline
\end{tabular}

*Recovery of anti-D IgG in one woman was only $8 \%$ and is not included.

There is no reason to believe that the lower recovery rates in our series were due to the fact that we did not measure plasma concentrations in the first six days after the injection of anti-D IgG in the pregnant women, because in the three non-pregnant women the highest plasma value was found on the 7 th and not on the 3rd day. Nevertheless, there is a report of two patients injected with radiolabelled gammaglobulin in whom the recovery rate was about $32 \%$ on the 5 th day and $20 \%$ on the 7 th day after the injection. ${ }^{9}$

Apart from that, our study shows large variations in the recovery rates and the biological half lives of anti-D IgG between the women, which are probably much more important than differences between absolute values.

One of the main purposes of this study was to evaluate the optimal dose of anti-D IgG for antenatal treatment of $\mathbf{R h}$ -

\section{References}

${ }^{1}$ Hermann M, Kjellman H. Rh-prophylaxis with immunoglobulin anti-D administered during pregnancy and after delivery. Acta Obstet Gynec Scand 1976;suppl 49:1-11.

2 Bowman JM, Chown B, Lewis M, Pollock JM. Rh isoimmunization during pregnancy: antenatal prophylaxis. Can Med Assoc $\mathcal{F}$ 1978;118:623-7.

${ }^{3}$ Bowman JM, Pollock JM. Antenatal prophylaxis of $\mathrm{Rh}$ isoimmunization: 28-weeks'-gestation service program. Can Med Assoc F 1978;118:627-30.

${ }^{4}$ Hughes-Jones N, Stevenson M. The anti-D content of IgG preparations for use in the prevention of Rh haemolytic disease. Vox Sang 1968;14: 401-8.

5 Sturgeon P, Cedergren B, McQuiston D. Automation of routine blood typing procedures. Vox Sang 1963;8:438-51.

${ }^{6}$ Hutchins CJ. Plasma volume changes in pregnancy in Indian and European primigravidae. Br 7 Obstet Gynaecol 1980;87:586-9.

7 Gibaldi M, Perrier D. Pharmacokinetics. New York: Marcel Dekker Inc, $1975: 281-92$

${ }^{8}$ Cohen S, Freeman T. Metabolic heterogeneity of human gammaglobulin Biochem F $1960 ; 76: 475-87$.

${ }^{9}$ Morell A, Schürch B, Ryser D, et al. In vivo behaviour of gammaglobulin preparations. Vox Sang $1980 ; 38: 272-83$.

${ }^{10}$ Smith GN, Griffiths B, Mollison D, Mollison PL. Uptake of IgG after intramuscular and subcutaneous injection. Lancet $1972 ; \mathrm{i}: 1208-12$.

11 Jouvenceaux A. Prévention de l'immunisation anti-Rh. Rev Fr Transfus $1971 ; 14: 39-51$.

12 Jouvenceaux A. Intravenous versus intramuscular anti-D. Paper given at Conference on Prevention of Rh immunisation, WHO Reference Centre for use of Anti-D Immunoglobulin, 1970.

13 Barandun S. Die Gammaglobulin-Therapie. Chemische, immunilogische, und klinische Grundlagen. Bibl Haematol 1964;17:1-134.

14 Martin-Du Pan R, Scheidegger JJ, Wenger P, et al. Das Verhalten der intramuskulär, intravenös, und per os verabreichten Gammaglobuline. Blut 1959;5:104-14. 